\title{
T-Cell Acute Lymphoblastic Leukemia
Presenting with Pleural Effusion: A Case Report
}

\section{ilk Bulgusu Plevral Effüzyon Olan T-Hücreli Akut Lenfoblastik Lösemi: Olgu Sunumu}

Hasan Furkan Avcı, Oğuzhan Okutan, Tayfun Çalışkan, Gözde Kalbaran Kısmet, Illyas Kocabağ

\begin{abstract}
Acute lymphoblastic leukemia is a heterogeneous group of lymphoid disorders that are linked to the monoclonal proliferation and expansion of immature lymphoid cells in the bone marrow, blood and organs. The clinical presentation of acute lymphoblastic leukemia is usually nonspecific, while symptoms typically include fatigue, lack of energy, easy bruising or obvious bleeding, dyspnea, dizziness and infections, and B symptoms such as fever, night sweats or weight loss can occur. Pleural effusion, as the first clinical manifestation of acute lymphoblastic leukemia, is relatively rare. We present here the case of a 55 year-old female patient diagnosed with T-cell Acute Lymphoblastic Leukemia based on examinations performed due to pleural effusion.
\end{abstract}

Key words: Adenosine Deaminase, Leukemia, pleurisy, pleural effusion.

\section{Özet}

Akut lenfoblastik lösemi, kemik iliği, kan ve diğer organlarda immatür lenfoid hücrelerin monoklonal proliferasyonu ve yayılımı ile sonuçlanan, lenfoid hastalıklar içinde heterojen bir hastalık grubudur. Klinik prezantasyonu genelde nonspesifiktir. Bunlar içinde en sık görülenleri, halsizlik, güç kaybı, kanamaya meyilde artış veya belirgin kanamalar, nefes darlığı, baş dönmesi ve enfeksiyonlardır. Ateş, gece terlemesi ve kilo kaybı gibi B semptomları da görülebilir. Akut lenfoblastik lösemi hastalarında ilk bulgu olarak plevral effüzyonun görülmesi nadir bir durumdur. Plevral effüzyon nedeniyle yapılan tetkikler ile THücreli Akut Lenfoblastik Lösemi tanısı konan 55 yaş kadın hasta, burada sunulmuştur.

Anahtar Sözcükler: Adenozin deaminaz, Lösemi, plörezi, plevral effüzyon.
Department of Chest Diseases, University of Health Sciences Turkey, Hamidiye Faculty of Medicine, Sultan II. Abdülhamid Han Health Application and Research Center, İstanbul, Turkey
Sağlık Bilimleri Üniversitesi, Sultan II.Abdülhamid Han Sağlık Uygulama ve Araşıırma Merkezi, Göğüs Hastalıkları Servisi, İstanbul

Submitted (Başvuru tarihi): 29.12.2020 Accepted (Kabul tarihi): 26.01.2021

Correspondence (iletişim): Hasan Furkan Avcl, Department of Chest Diseases, University of Health Sciences Turkey, Hamidiye Faculty of Medicine, Sultan II. Abdülhamid Han Health Application and Research Center, İstanbul, Turkey

e-mail: hfavci@yahoo.com 
The clinical presentation of acute lymphoblastic leukemia (ALL) is usually nonspecific. Fatigue, lack of energy, easy bruising or obvious bleeding, dyspnea, dizziness and infection are commonly seen with $A L L$, while $B$ symptoms such as fever, night sweating and weight loss may also be detected (1). As its first manifestation, pleural effusion is relatively rare (2). We presented the case of a 55-yearold female who was admitted to the emergency service with dyspnea and chest pain, and who was diagnosed with ALL from an evaluation of pleural effusion.

\section{CASE}

A 55-year-old woman was admitted to the emergency service of our hospital with dyspnea and chest pain lasting for 2 weeks. She had essential hypertension and reported no smoking or lung disease history. A physical examination revealed an increased respiratory rate (22/minute), and oxygen saturation, evaluated with pulse oximetry $\left(\mathrm{SpO}_{2}\right)$, was $91 \%$ in room air. Upon auscultation, lower respiratory sounds were heard in the left hemithorax than in the right. A postero-anterior chest X-ray revealed a homogenous opacity consistent with pleural effusion, reaching the upper zone and causing a mediastinal shift to the left side (Figure 1). Based on these findings, the patient was hospitalized in the pulmonary medicine ward to workup pleural effusion etiology. The baseline laboratory values of the patient were as follows: Urea, $63 \mathrm{mg} / \mathrm{dl}$; serum creatinine, $1 \mathrm{mg} / \mathrm{dL}$; albumin, $45 \mathrm{~g} / \mathrm{L}$; C-reactive protein (CRP), $7.9 \mathrm{mg} / \mathrm{L}$; brain natriuretic peptide (BNP),

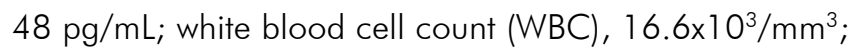

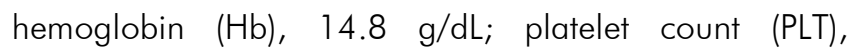
$277 \times 10^{3} / \mathrm{mm}^{3}$; neutrophil proportion, 66\%; neutrophil count, $\quad 10.99 \times 10^{3} / \mathrm{mm}^{3}$; lymphocyte count, $4.02 \times 10^{3} / \mathrm{mm}^{3}$; and monocyte count, $1.51 \times 10^{3} / \mathrm{mm}^{3}$. The patient was subsequently placed on $2 \mathrm{~g} /$ day ceftriaxone IV and $500 \mathrm{mg} / 12 \mathrm{~h}$ clarithromycin PO. Despite the one-sided pleural effusion, and echocardiography was performed to exclude congestive cardiac failure. The ejection fraction, cardiac valve functions and structures were reported as normal. A pericardial effusion of $16 \mathrm{~mm}$ thickness that was not causing cardiac tamponade was also detected, and medical treatment was arranged by a cardiologist.

After the patient was informed and signed a consent form, a pleural catheter was applied to the 7th intercostal space and serofibrinous pleural fluid was drained, and the sample was examined cytologically, biochemically and microbiologically. The effusion was classified as exudate according to the Light Criteria. The biochemical results of the pleural fluid were as follows: fluid glucose, $28 \mathrm{mg} / \mathrm{dL}$; total protein, $40 \mathrm{~g} / \mathrm{L}$; lactate dehydrogenase (LDH), 5236 $\mathrm{U} / \mathrm{L}$; and albumin, $30 \mathrm{~g} / \mathrm{L}$. The culture results for bacteria, fungi and mycobacteria were negative, and the adenosine deaminase (ADA) level was significantly high at $1,167 \mathrm{U} / \mathrm{L}$.

Compression atelectasis attributed to a mass lesion on the medial segment of the middle lobe was encountered in a chest computed tomography (CT) (Figure 2). No endobronchial lesion was identified during fiber-optic bronchoscopy (FOB) and the cytology results of a bronchial lavage were negative for malignancy. Microbiological results showed no bacterial-fungal or mycobacterial organisms on culture. After a total of $2000 \mathrm{ml}$ of fluid was drained, the pleural catheter was removed. A positron emission tomography/CT (PET/CT) revealed increased FDG uptakes of the supraclavicular, mediastinal, axillary, supraphrenic, coeliac, paraaortic and perilymphatic lymph nodes. The right pleura's FDG uptake was SUVmax: 3.9. The mass lesion detected on chest CT was reported as a mediastinal lymph node with increased FDG uptake (SUVmax: 8.9) on PET/CT, and this result was compatible with malignant proliferative disorder (Figure 3).

Since the patient had no symptoms and needed no supplementary oxygen, she was discharged. Two weeks after being discharged, her dyspnea improved but edema developed bilaterally in the lower limbs, and she was readmitted to hospital. Her laboratory results were as follows: urea, $50 \mathrm{mg} / \mathrm{dL}$; creatinine, $0.99 \mathrm{mg} / \mathrm{dL}$; BNP, $96 \mathrm{pg} / \mathrm{mL} ;$ AST, $59 \mathrm{U} / \mathrm{L} ; A L T, 61 \mathrm{U} / \mathrm{L}$; and CRP, 62.3 $\mathrm{mg} / \mathrm{L}$. Her WBC increased to $110.2 \times 103 / \mathrm{mm}^{3}$ and $\mathrm{Hb}$ and her platelet count was $13.4 \mathrm{~g} / \mathrm{dL}$ and $82 \times 10^{3} / \mathrm{mm}^{3}$. A peripheral blood smear examination revealed $8 \%$ polymorphnuclear leukocyte (PMNL), 3\% lymphocytes and $89 \%$ blast cells. The cytology result of the pleural fluid was reported as: "TDT positive, atypical lymphoidal infiltration, compatible with T-Cell Lymphoblastic Leukemia". HYPER-CVAD chemotherapy was started and has been continued for 1 month, and the patient's dyspnea and other symptoms have disappeared.

\section{DISCUSSION}

$\mathrm{ALL}$ is a heterogeneous hematologic disease, characterized by immature lymphoid cell proliferation in the bone marrow, peripherical blood and organs (1). Its incidence has been reported as 1.38/100,000 in the United States (3), with $55 \%$ of patients diagnosed before the age of 20 years, and $28 \%$ diagnosed after 45 years of age, since 
the mean age at diagnosis is $15(4,5)$. ALL accounts for $75-80 \%$ of all leukemia cases in childhood, compared to $20 \%$ in adults (6). As leukemia is a disease that may invade all organs and tissues, pleural invasion may occur, but it is rare and is generally diagnosed after autopsy (7). Pleural effusion may occur due to lymphatic drainage failure and with multiple mechanisms, including lymphadenopathy, thoracic duct obstruction, pleural or pulmonary invasion of tumoral cells, venous obstruction, pulmonary infection and radiation therapy (8). We report here on a relatively rare case of ALL with pleural effusion as the initial clinical finding, caused possibly by mediastinal lymphadenopathy and pleural drainage failure due to mechanical pressure.

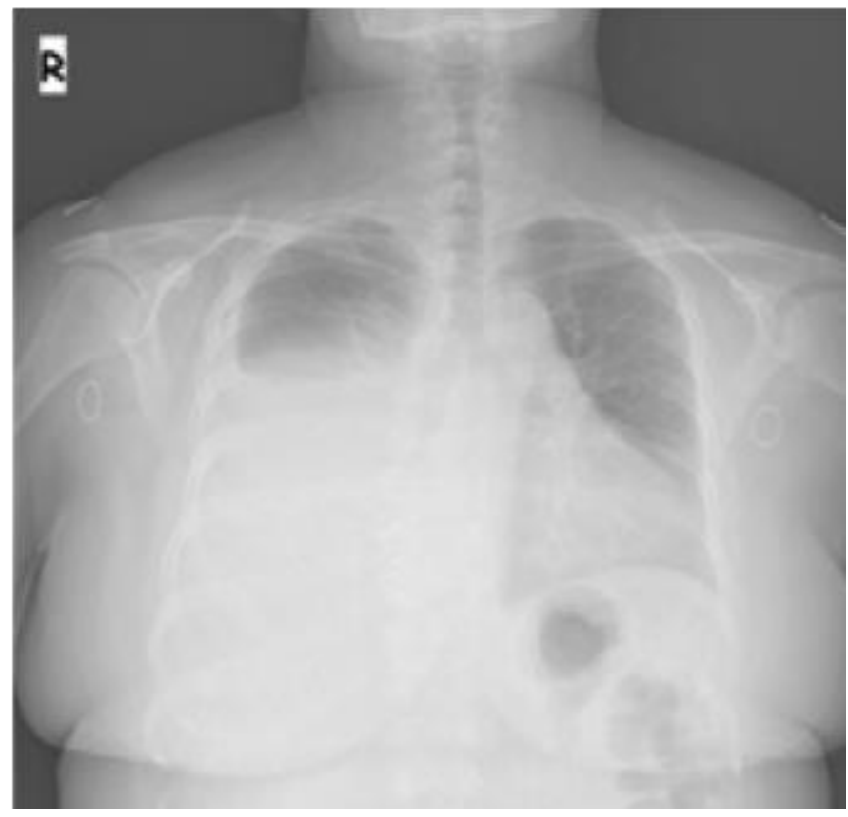

Figure 1: Homogenous density increase in the right lung erasing the diaphragm contour, extending to the upper zone and deviating in the mediastinum to the opposite side

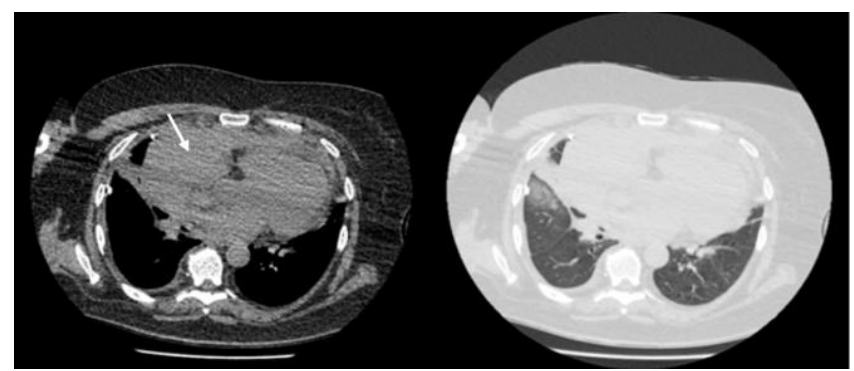

Figure 2: Thoracic CT taken after drainage catheter. In mediastinum and parenchyma window, the area thought to be loculated effusion in first sight (white arrow) and compression atelectasis adjacent to this area

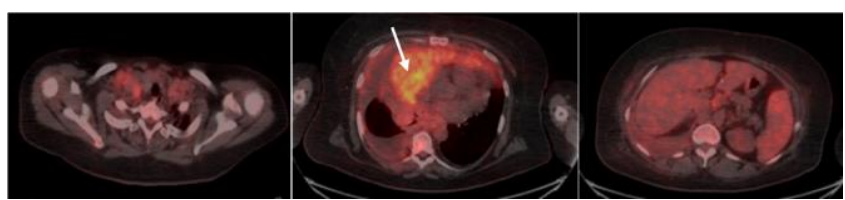

Figure 3: PET-CT fusion image. A mass lesion which is compatible with a conglomerated lymph node shown with white arrow, measuring $12 \times 8$ $\mathrm{cm}$ in its widest part, its borders are indistinguishable from the aortic arch and vena cava superior

A minimum $60 \mathrm{ml}$ pleural effusion is required to make a cytological diagnose from a malign pleural effusion by a direct smear analysis. If combined with a cell block analysis, at least $150 \mathrm{ml}$ of pleural fluid should be measured (9). We have sent to pathology approximately $1,000 \mathrm{ml}$ pleural fluid collected by pleural drainage catheter, and the diagnosis has been confirmed based only on pleural fluid assessment. Also, the level of ADA of $1167 \mathrm{U} / \mathrm{L}$ on pleural fluid was remarkable. ADA is an aminohydrolase enzyme that catalyzes adenosine to inosine, and is elevated in areas with excess lymphoid cells such as the lymph nodes, spleen, Peyer's plaques and thymus. Higher ADA levels develop in lymphoid malignancies. ADA activity may be normal, increased or decreased in leukemia cells, and are reported to be significantly increased in ALL, especially in T cell-ALL (10). ADA levels are increased more commonly than other etiologies in malignant pleural effusions. In a retrospective study of 2,104 patients, it was observed that pleural fluid ADA levels did not exceed $250 \mathrm{U} / \mathrm{L}$ in tuberculosis patients that 19 of 22 patients with higher pleural ADA levels than this had empyema, and that three of the 22 had lymphoid malignancies (11).

\section{CONCLUSION}

Pleural effusion may develop for many etiological reasons, with malignant pleural effusions being one of the more common among these. Pleural fluid sampling is an easy and cost-effective examination with a prime position among diagnostic tests of malignancy. While a definitive diagnosis can be made with a cytological examination, microbiological and biochemical tests should be made and evaluated together for differential diagnosis. T cell$\mathrm{ALL}$ is a diagnosis that should be kept in mind in patients investigated for pleurisy, especially in patients whose ADA values are higher than expected. 


\section{CONFLICTS OF INTEREST}

None declared.

\section{AUTHOR CONTRIBUTIONS}

Concept - H.F.A., O.O., T.Ç., G.K.K., I..K.; Planning and Design - H.F.A., O.O., T.Ç., G.K.K., I.K.; Supervision H.F.A., O.O., T.Ç., G.K.K., I.K.; Funding - H.F.A., T.Ç.; Materials - G.K.K., O.O.; Data Collection and/or Processing - H.F.A., O.O.; Analysis and/or Interpretation O.O., T.Ç.; Literature Review - H.F.A., G.K.K.; Writing H.F.A.; Critical Review - T.Ç.

\section{YAZAR KATKILARI}

Fikir - H.F.A., O.O., T.Ç., G.K.K., I.K.; Tasarım ve Dizayn - H.F.A., O.O., T.Ç., G.K.K., I.K.; Denetleme H.F.A., O.O., T.Ç., G.K.K., I.K.; Kaynaklar - H.F.A., T.Ç.; Malzemeler - G.K.K., O.O.; Veri Toplama ve/veya İşleme - H.F.A., O.O.; Analiz ve/veya Yorum - O.O., T.Ç.; Literatür Taraması - H.F.A., G.K.K.; Yazıyı Yazan - H.F.A.; Eleştirel İnceleme - T.Ç.

\section{REFERENCES}

1. Jabbour EJ, Faderl S, Kantariian HM. Adult acute lymphoblastic leukemia. Mayo Clin Proc 2005; 80:1517-27. [CrossRef]

2. Peruzzi B, Cutini I, Gelli AM, Rondelli T, Statello M, Bencini $S$, et al. Diagnosis of a $T$-lineage acute lymphoblastic leukemia through digitalized cell analysis of the pleural effusion. Int Med Case Rep J 2013; 6:77-80. [CrossRef]

3. National Cancer Institute, Surveillance, Epidemiology and End Result (SEER) Program Cancer Statistics Review (CSR) 1975-2015: Leukemia, annual incidence rates (acute lymphoblastic leukemia) 2018. Place of Access: https://seer.cancer.gov/csr/1975_2015/ Accessed on July 14, 2020.
4. National Cancer Institute, Surveillance, Epidemiology and End Result (SEER) Program Cancer Statistics Review (CSR) 1975-2015: Overview, median age at diagnosis. 2018. Place of Access: https://seer.cancer.gov/csr/1975_2015/ Accessed July 14, 2020.

5. National Cancer Institute, Surveillance, Epidemiology and End Result (SEER) Program Cancer Statistics Review (CSR) 1975-2015: Age distribution of incidence cases by site. 2018. Place of Access: https://seer.cancer.gov/csr/1975_2015/ Accessed July 14, 2020.

6. Esparza SD, Sakamoto KM. Topics in pediatric leukemia-acute lymphoblastic leukemia. MedGenMed 2005; $7: 23$.

7. Dix DB, Anderson RA, McFadden DE, Wadsworth LD. Pleural relapse during hematopoietic remission in childhood acute lymphoblastic leukemia. J Pediatr Hematol Oncol 1997; 19:470-2. [CrossRef]

8. He XL, Yu F, Guo T, Xiang F, Tao XN, Zhang JC, et al. Tcell lymphoblastic lymphoma presenting with pleural effusion: A case report. Respir Med Case Rep 2014; 12:558. [CrossRef]

9. Swiderek J, Morcos S, Donthireddy V, Surapaneni R, Jackson-Thompson V, Schultz $L$ et al. Prospective study to determine the volume of pleural fluid required to diagnose malignancy. Chest 2010; 137:68-73. [CrossRef]

10. Morisaki T, Fujii H, Miwa S. Adenosine deaminase (ADA) in leukemia: clinical value of plasma ADA activity and characterization of leukemic cell ADA. Am J Hematol 1985; 19:37-45. [CrossRef]

11. Porcel JM, Esquerda A, Bielsa S. Diagnostic performance of adenosine deaminase activity in pleural fluid: a singlecenter experience with over 2100 consecutive patients. Eur J Intern Med 2010; 21:419-23. [CrossRef] 